INTEGRASI KONSEP TASAWUF-SYARIAT SYAIKH ABDUL QADIR ALJAILANI (QUTUBUL AULIYA)

\title{
Fitrotul Muzayanah
}

\author{
Prodi Sejarah Kebudayaan Islam, Fakultas Islam Nusantara, Universitas \\ Nahdlatul Ulama Indonesia (UNUSIA) \\ Email: fitrotulmuzayanah@ unusia.ac.id
}

\section{Article Information \\ http://journal.unusia. ac.id/index.php/moz aic/}

DOI:

10.47776/mozaic.v7i

1.168

\section{Informasi Artikel}

Naskah diterima: 20

Februari 2021

Naskah direvisi: 20

April 2021

Naskah disetujui: 24

April 2021

Naskah dipublish:

25 April 2021

\section{Keywords}

Integration

Tasawuf-Sharia Al-

Jailani, Qutubul

Auliya

\section{Kata Kunci \\ Integrasi Tasawuf- Syariat, Al-Jailani, Qutubul Auliya}

\begin{abstract}
Abstact
The Muslim community still thinks that Sufism and Sharia are different things. In fact, from the beginning, Islam has instilled the teachings of a spiritual element and balanced heart management between Sufism and Shari'a, because they can't stand alone but must be mutually sustainable in the practice of life. Al-Jailani is the imam of the Sufis (Qutubul Auliya) describing Sufism which is integrated into the sharia of human worship in the daily activities of Muslims in general. This writing conceptualizes Al-Jailani's thoughts using a qualitative descriptive method approach. The collection of data is taken using the research library research technique. The theory used uses the theory of social integration to unite different elements so that they become one understanding so as not to cause conflicts of misunderstanding in society. Based on the results of research tracing, it was obtained an explanation that Sufism al-Jailani was able to integrate Sufism and Sharia in a practical-applicable manner as an absolute prerequisite for achieving safety in this world and the hereafter. Because in essence ma'rifat must be passed by mujahadah and self-cleansing. Sufism in the view of al-Jailani is a progressive, active and positive Sufism. Seeing the world in the balance of the hereafter.
\end{abstract}

\section{Abstrak}

Masyarakat muslim awam masih beranggapan tasawuf dan of syariat merupakan hal yang berbeda. Hal ini sebetulnya dalam agama Islam dari awal sudah menanamkan ajaran unsur spritual dan manajemen hati yang seimbang antara tasawuf dan syariat, karena mereka tidak bisa berdiri send iri melainkan harus saling berkesinambungan dalam laku kehidupan. Al-Jailani merupakan imamnya para sufi (Qutubul Auliya) menggambarkan tasawuf yang diintegrasikan ke dalam syariat ibadah manusia dalam keseharian aktivitas muslim pada umumnya. Penulisan ini menkonsepkan pemikiran Al-Jailani menggunakan pendekatan kualitatif metode deskriptif. Pengumpulan data yang diambil menggunakan teknik studi literatur library research. Teori yang digunakan menggunakan teori integrasi sosial menyatukan unsur yang berbeda sehingga menjadi satu pemahaman sehingga tidak menimbulkan konflik kesalahpahaman dalam masyarakat. Berdasarkan 
hasil penelusuran penelitian, diperoleh penjelasan bahwa tasawuf al-Jailani mampu mengintegrasikan antara tasa w uf dan syariat secara praktis-aplikatif sebagai syarat mutlak untuk meraih keselamatan di dunia dan akhirat. Karena hakekatnya ma'rifat harus dilalui dengan mujahadah dan pembersihan diri. Sufisme dalam pandangan al-Jailani merupakan sufisme yang progresif, aktif dan positif. Memandang dunia dalam keseimbangan akhirat.

\section{PENDAHULUAN}

Dalam sejarah dan perkembangan masyarakat muslim, sufisme merupakan dimensi Islam yang sangat kontoversial. Hakikatnya dan eksistensinya sering kali disalahpahami dan diremehkan. Tuduhan dan kritik terhadap tasawuf memang sering kali tidak beralaskan. Karena tuduhan dan kritik biasanya datang dari golongan yang tidak memahami tasawuf secara komprehensif dan mendalam, serta tidak melihatn ya dari perspektif sufi. Secara teologis sesungguhnya tasawuf memiliki dasar doktrin yang kuat dalam al-Qur'an dan sunnah. Sekaligus memiliki akar yang lebih kuat di dalam al-Qur'an dibandingkan dengan syari'at.

Bagi para sufi, sebetulnya tasawuf dan syari'at tidak dipandang sebagai dua dimensi yang bertentangan, akan tetapi mereka saling melengkapi satu sama lain dan merupakan dari satu kesatuan yang tak terpisahkan. Meskipun demikian, dalam sejarah dan perkembangan masyarakat masih banyak terjadi pertentangan dan konflik antara kedua penganut dimensi Islam tersebut.

Seiring dengan berjalannya sejarah peradaban Islam, telah muncul ditengah tengah masyarakat yang ahli dalam bidang tasawuf dan melahirkan konsep masingmasing. Banyak perbedaan dan persamaan yang muncul diantara mereka. Jelasnya tasawuf merupakan tradisi keilmuan Islam yang berjasa sebagai disiplin ilmu dan mampu memberikan solusi kepada manusia yang merasa belum puas dengan ibadah formal yang sudah ditentukan oleh ahli fiqih.

Sebagai seorang sufi sekaligus ulama besar, syekh Abdul Qadir Al-Jailani adalah sosok yang mampu menjembatani kesenjangan yang terjadi antara ajaran tasawuf dan fiqih. Sehingga antara ajaran tasawuf dan fiqih bisa berjalan bersama. Syekh Abdul Qadir Al-Jailani juga salah satu tokoh sufi yang paling terkemuka dan memiliki pengaruh paling besar di dunia Islam. Beliau dari dulu sampai sekarang 
dikenal dengan sebutan penguasa, pemimpin para wali (Sulthan al-Auliya'), Qutubul Auliya' dan imam para sufi. Beliau merupakan tokoh spiritual muslim yang benarbenar menghidupkan ruh Islam yang sejati yang bersanding bersama keindahan karomah-karomah yang sangat luar biasa sehingga mendapat predikat muhyiddin penghidup agama, disini penulis ingin menelusuri dan mengenal lebih jauh tentang ajaran dan konsep tasawuf dari syekh Abdul Qadir Al-Jailani dari segi tasawuf dan fiqih. Penulisan ini penting karena biasanya tasawuf dan fiqih tidak sejalan di mata masyarakat. Fiqih lebih bercorak pada simbolistik, legalistik, eksoterik dan formalistik. Cenderung melihat sebuah tindakan dari syarat dan rukun, sah dan tidak sah. Sementara bertasawuf adalah identik dengan pola hidup asketik dan ke pasrah an hidup statis. ${ }^{1}$

Sebagai pelengkap data dan pembeda dari penulisan yang lain, penulis menampilkan tinjauan pustaka melalui jurnal yang ditulis Kafrawi berjudul Pemikiran Syekh Abdul Qadir Al-Jailani Tentang Makrifat. ${ }^{2}$ Hasil penelitiannya hanya mendeskripsikan konsep ma'rifah secara umum, bahwa untuk mencapai ma'rifah harus menjalani dzikir, tafakur, syukur, fana dan baqa, muhadarah, mukasyaw ah dan mushahadah. Jenis penelitiannya menggunakan pendekatan deskriptif kualitatif. Teknik pengumpulan data dengan cara mendokumentasikan data dari buku yang relevan.

Sedangkan tinjauan kedua, penulis menggunakan literatur jurnal milik Mahbub Junaidi yang berjudul Pemikiran Kalam Syekh Abdul Qadir al-Jailani. ${ }^{3}$ Dalam penelitiannya berfokus mengkaji tentang tauhid yang menjelaskan bah wa alJailani mengarajarkan ketauhidan secara garis besar dibangun oleh konsep Ahlu Sunnah Waljamaah. Dalam penulisan tersebut tidak menyebutkan penggunaan metode penelitian dan pengumpulan data sebagai karakter sebuah penelitian. Dalam kajian penelitian lain penulis membedakan yang dibahas oleh Moh. Ashif Fuadi \&

\footnotetext{
${ }^{1}$ Ali Mas'ud \& Ah. ZakkiFuad, Fiqih dan Tasawuf dalam Pendekatan Historis, Ju rnal HUMANIS Vol. 10, No. 1, Ja nuari2018, h. 11.

${ }^{2}$ Kafrawi, Pemikiran Syekh Abdul Qadir Al-Jailani Tentang Ma'rifat, Jurnal Al-Liq o Pendidik an Islam, Vol. V, No. 1, 2020, h. 78.

${ }^{3}$ Mahbub Junaidi, Pemikiran Kalam Syekh Abdul Qadir al-Jailani, e-Jurnal Unisda.ac.id, h. 162.
} 
Rustam Ibrahim yang berjudul Implementasi Tasawuf Syekh Abdul Qadir al -Jailani dalam Majelis Manakib al-Barokah Ponorogo. ${ }^{4}$

Dalam kajian ini berfokus pada implementasi atau praktek lapangan yang dilakukan Majelis Manakib al-Barokah Ponorogo yang sudah dilakukannya rutin setiap tanggal 11 bulan Hijriyah. Kajian penulisan tersebut memadukan sumber pustaka dan pengamatan lapangan. Menjadi menarik tema dalam penulisan ini adalah perbedaan dalam pembahasan dengan tema besar yang sama yaitu membahas alJailani, namun yang menjadi pembeda adalah penulis lebih spesifik mencari data integrasi dalam konsep tasawuf dan syariat pada pemikiran al-Jailani. Dengan tujuan supaya masyarakat mampu memahami bagaimana proses penyatuan antara tasawuf dan syariat dalam pemikiran al-Jailani.

Intinya penulisan ini berusaha bagaimana mengelaborasi integrasi syariat, khususnya fikih dengan tasawuf pada pemikiran al Jailani pada tataran kon sep dan penerapan yang merupakan modal pokok dalam membangun kepribadian Muslim. Upaya ini dimaksudkan untuk menguatkan kembali kepribadian Muslim yang dewasa ini terasa rapuh agar kembali kokoh dan memiliki integritas. Memberikan tekanan kepada salah satu di antara syariah dan tasawuf, apalagi memisahkan di antara keduanya, akan menghasilkan kepincangan dan menyalahi prinsip keseimbangan dalam Islam.

\section{METODE PENELITIAN}

Penelitian ini menggunakan pendekatan deskriptif kualitatif library research yaitu mengumpulkan buku-buku utama karya Al-Jailani berkaitan dengan objek penelitian yang bersifat kepustakaan. Penulis menggunakan sumber data primer dan sekunder. Data primer yang digunakan adalah rujukan utama dalam penelitian seperti buku rujukan awal dan utama dalam penulisan yaitu: Aik Iksan Anshori, desertasi dengan judul Tafsir Ishari Pendekatan Hermeneutika Sufistik Tafsir Abdul Qadir alJailani, Ciputat: 2012. Abdul Qadir Al-Jailani, al-Fath ar-Rabbany wa al-Faidh arRahmany (Kairo: Dar ar-Rayyan li at-Turats, tt). Kitab Sirr al-Asrar wa Madhhar alAnwar, Kairo: Mathba'ah al-Mishriyah. Kitab al-Ghunyah li Thalib Thariq al-Haqq,

\footnotetext{
${ }^{4}$ Moh. Ashif Fua di \& Rustam Ibrahim, Implementasi TasawufSyekh Abdul Qadir al-Jailani da lam Majelis Manakibal-Barokah Ponorogo, Jurnal Al-Ada biya: Jurnal Kebudayaan dan Keagamaan, Vo. 15 No.02 Juli-Desember 2020, h. 215.
} 
Vol. II, Beirut: Dar al-Ihya at-Turats al-‘Arab, 1996. Kitab Abdul Qadir al-Jailani, Futuhul Ghoib (Maktabah wa Matba'ah Mustofa: Mesir, 1973). Buku Abdul Qadir alJailani, Futuhul Ghoib Penyingkap Keghaiban (Titah Surga: Yogyakarta, 2015).

Data sekunder yang digunakan oleh penulis adalah hasil pengumpulan yang dilakukan oleh orang lain dengan maksud tertentu dan mempunyai kategori, klasifikasi menurut keperluan masing-masing dan kegunaan penulis masing-masing. ${ }^{5}$

Dalam hal ini sumber data yang bersifat sekunder adalah buku rujukan pendukung dan jurnal penelitian pendukung untuk membedakan suatu penelitian dalam penulisan dengan tujuan sehingga ada hal yang menarik dalam tulisan ini. Rujukan pendukungnya yaitu: Kafrawi, Pemikiran Syekh Abdul Qadir Al-Jailani Tentang Ma'rifat, Jurnal Al-Liqo Pendidikan Islam, Vol. V, No. 1, 2020. Mahbub Junaidi, Pemikiran Kalam Syekh Abdul Qadir al-Jailani, e-Jurnal Unisda.ac.id. Moh. Ashif Fuadi \& Rustam Ibrahim, Implementasi Tasawuf Syekh Abdul Qadir al-Jailani dalam Majelis Manakib al-Barokah Ponorogo, Jurnal Al-Adabiya: Jurnal Kebudayaan dan Keagamaan, Vo. 15 No. 02 Juli-Desember 2020.

Sehingga penulis menggunakan teknik pengumpulan data dengan cara mendokumentasikan penelitian terdahulu melalui buku yang relevan maupun penelitian yang relevan. ${ }^{6}$ Penulis menggunakan teknik analisis data dengan cara teknik analisa data kajian isi (countent analysis). Kajian penulisan ini memanfaatkan sumber utama kitab karangan al-Jailani dan penelitian-penelitian yang sudah pernah dikaji sehingga bisa menarik kesimpulan dengan permasalahan fakta yang ada di masyarakat muslim. Kajian ini bersifat deduktif dan bisa bersifat kajian induktif. ${ }^{7}$

\section{KAJIAN TEORI}

\section{Integrasi Sosial}

Dalam penulisan ini penulis menggunakan kajian teori yang relevan yaitu teori Integrasi Sosial. Secara etimologis, integrasi merupakan kata serapan dari bahasa inggris, integrate, integration yang kemudian diadaptasi ke dalam bahasa In donesia

\footnotetext{
${ }^{5}$ S. Na sotion, Metode Research Penelitian Ilmiah (Jakarta:Bumi Aksara, 2002), cet. 5.h. 143.

${ }^{6}$ Riduan, Belajar Mudah Penelitian Untuk Guru, Karyawan dan Peneliti Pemula (Bandung: Alfabeta, 2015), h. 12.

${ }^{7}$ Lexy J. Moleong, Metodologi Penelitian Kualitatif (Bandung: Remaja Rosdakarya. 2013), cet. 31, h. 220.
} 
menjadi integrasi yang berarti menyatu-padukan, penggabungan ${ }^{8}$ atau penyatuan menjadi satu kesatuan yang utuh.

Adapun secara terminologis, pemaduan atau penyatuan dari unsur yang berbeda sehingga menjadi kesatuan yang utuh. ${ }^{9}$ Proses integrasi sendiri melalui beberapa tahapan diantaranya: Integrasi interpersonal yaitu taraf ketergantungan antar pribadi, Integrasi, sosial yaitu taraf ketergantungan antara unsur-unsur sosial ekonomi, dan Integrasi budaya yaitu ketergantungan fungsional dari unsur-unsur kebudayaan . Dalam kamus Sosiologi, Soekanto mengartikan integrasi sebagai pengendalian terhadap konflik dan penyimpangan dalam suatu sistem sosial. ${ }^{10}$

Landecker membedakan tipe-tipe integrasi menjadi empat yakni: Integrasi budaya atau konsisten diantara standar budaya, Integrasi normatif atau konsistensi antara standar budaya dan tingkah laku masyarakat, Integrasi komunikatif atau adanya jaringan komunikasi yang sesuai dengan sistem sosial, Integrasi fungsional atau tingkatan yang disana ada hubungan kebebasan di antara unit-unit dari sistem pembagian tenaga kerja. ${ }^{11}$

Sehingga integrasi memiliki makna dibangunnya interdepensi yang lebih erat antara bagian-bagian dari anggota dalam masyarakat atau organisme hidup atau dengan kata lain integrasi adalah proses mempersatukan masyarakat yang cenderung membuatnya menjadi suatu kata harmonis yang didasarkan pada tatanan anggotaanggotanya dianggap sama harmonisnya.

Integrasi merupakan salah satu topik menarik untuk dikaji, untuk menjelaskan bagaimana berbagai pandangan masyarakat yang berbeda menjadi kesatuan pemahaman dan terintegrasi satu dengan yang lain. Hakikat integrasi dalam kajian penulisan ini adalah melalui pemahaman agama syariat dan tasawuf al-Jailani mampu menyatukan keduanya untuk dapat membersihkan diri dari jiwa akhlak yang tidak baik menjadi insan yang dicintai Allah.

\section{INTEGRASI FIKIH DAN TASAWUF SEBAGAI MODAL PENGEMBANGAN KEPRIBADIAN MUSLIM.}

\footnotetext{
${ }^{8}$ John M. Echlos dan Hassan Shadily, Kamus Inggris-Indonesia (Jakarta: PT. Gra media Pu staka Utama, 2003), h. 326.

${ }^{9}$ Soerjono Soekanto, Kamus Sosiologi (Jakarta: Rajawali Press, 1983), h. 157

${ }^{10}$ Soerjono Soekanto, Kamus Sosiologi, h. 158.

${ }^{11}$ David L.Silis (ed), International Encyclopedia of the Sosial Sciences, Vol.7 (New York: The Ma cmillan Company \& The Free Press, 1986), 381
} 
Ada lima komponen yang menjadi dasar pengem-bangan kepribadian Muslim. Dasar pertama adalah akidah yang benar, yang berdiri di atas keimanan y ang benar, yang mendorong pada tindakan yang lurus. Dasar kedua ada model ideal yang menjadi uswah hasanah, teladan yang baik. Dasar ketiga adalah kapasitas diri untuk menjadi manusia pembelajar yang mencintai ilmu dan menerapkan ilmu dalam kehidupannya. Dasar keempat adalah ketekunan beribadah yang menjadikan dirinya senantiasa membutuhkan Allah. Dasar kelima adalah semangat berjihad yang mendorong seseorang untuk mewujudkan apa yang menjadi cita-cita ideal dalam hidupnya. ${ }^{12}$

Rasulullah Saw. adalah figur sentral yang menjadi uswah hasanah, teladan yang baik, bagi umat Islam dalam kehidupan sosial, intelektual, dan penghayatan nilai-nilai spiritual ${ }^{13}$ memadukan model pengamalan agama yang memenuhi kebutuhan biologis dan sosial umat Islam secara legal formal yang tercermin pada hukum fikih yang mencakup aspek ibadah dan muamalah. pada waktu yang sama sangat memperhatikan pembersihan diri dari segi kejiwaan yang meliputi penyucian jiwa, pengendalian diri, kekayaan batin, keikhlasan lahir batin, khusyuk kepada Allah, kerendahan hati, kedermawanan, dan pengabdian yang tulus. ${ }^{14}$

Dengan memadukan fikih dan tasawuf atau hukum dan moralitas dalam menjalani kehidupan, maka akan melahirkan pribadi yang menjaga keseimbangan antara kebutuhan kebendaan dan kebutuhan spiritual, antara kehidupan in dividu dan kehidupan sosial, serta kehidupan yang berorientasi duniawi dan kehidupan yang berorientasi ukhrawi.

Seorang yang memadukan pengamalan syariah dengan tasawuf secara baik dan benar akan menghindari paham spiritualisme yang tercermin dalam gay a hidup berikut ini: (1) lebih mengutamakan dimensi batin dari-pada dimensi lahir; (2) lebih memilih pola hidup asketis (zuhd) dengan khalwah, 'uzlah, dan tirakatan sebagaimana tergambar pada corak kehidupan para pertapa; (3) lebih mengutamakan kepuasaan

\footnotetext{
${ }^{12}$ Lihat Ahmad Umar Hasyim, Menjadi Muslim Ka ffah Berdasarkan Al-Qur`an dan Sunah Na bi sa w, diterjemahkan oleh Joko Suryanto dari buku, "Syahshiyah Muslim", (Makkah: Maktabah alTija riyyah), cet. ke-2,(Yogyakarta: Mitra Pustaka, 2005), h. 13-64

${ }^{13}$ Alquran menyebutkan, "Sungguhtelah ada pada diri Rasulullahitu tela dan yang baik bagi kamu (kaum Muslimin)". (Q.s. al-Ahzâb: 33:21)

${ }^{14}$ Lihat, Ahmad Umar Hasyim, Menjadi Muslim Kaffah Berdasarkan Al-Qur`an dan Sunah Nabi sa w, h. 203 .
} 
spiritual yang bersifat individual daripada tanggung jawab sosial yang bersifat kolektif; dan (4) memandang segala bentuk kebendaan (materi) sebagai sesuatu yang rendah, hina, dan sebagai faktor penghalang pengembangan kualitas ruhani; serta (5) memandang aktivitas muamalah seperti bekerja, berdagang, bertani dengan mempunyai isteri dan anak sebagai tindak mencintai dunia yang hina. ${ }^{15}$

Pada waktu yang sama, seorang yang memadukan pengamalan fikih dengan tasawuf akan menjauhi pola hidup hedonis. Menurut paham ini, suatu perbuatan dinyatakan baik apabila perbuatan tersebut mendatangkan kelezatan, kenikmatan, dan kepuasan secara biologis.

Demikian sebaliknya, suatu perbuatan dinyatakan buruk, apabila perbuatan itu tidak mendatangkan kelezatan, kenikmatan dan kepuasan secara biologis. Jadi, kelezatan, kenikmatan dan kepuasan biologis menjadi ukuran dalam menilai baik dan buruknya suatu perbuatan. Aliran Hedonisme merupakan pemikiran filsafat Epicurus (341-270 SM) yang ketika pertama dicetuskan menyebutkan bahwa kelezatan, kenikmatan, dan kepuasan yang menjadi ukuran baik dan buruknya suatu perbuatan itu tidak hanya secara biologis, tetapi juga secara rohani dan intelektual. Namun, pada perkembangan selanjutnya hedonisme hanya menilai baik dan buruknya suatu perbuatan dari segi kelezatan, kenikmatan, dan kepuasan biologis saja. Menurut aliran ini, minuman keras, berjudi, pornoaksi, pornografi, berbuat mesum, dan berzina adalah perbuatan baik, apabila tindakan itu mendatangkan kelezatan, kenikmatan, dan kepuasan biologis. ${ }^{16}$

Substansi syariat atau fikih adalah aturan-aturan dan norma-norma hukum yang memberikan arah dan tujuan agar ibadah, pengabdian dan penyerahan diri manusia kepada Allah dilakukan dengan benar sesuai dengan kehendak Allah sebagaimana digariskan di dalam Alquran dan Sunah Nabi Muhammad Saw., serta membawa dampak pada penyucian jiwa dan pendekatan diri kepada Allah. Syariat atau hukum Islam tidak dapat dipisahkan dari dimensi akhlak.Bahkan dalam keadaan tertentu dituntut untuk mengedepankan akhlak atas hukum. Di dalam Alquran banyak mengajarkan semangat mendahulukan kemurahan hati dan kebajikan daripada

\footnotetext{
${ }^{15}$ Ahmad Umar Hasyim, Menjadi Muslim Kaffah Berdasarkan Al-Qur`an dan Sunah Nabi saw, h. 568

${ }^{16}$ Asep Usman Ismail dkk., dalam Sri Mulyati, (ed), Tasawuf, cet. ke-1, (Jakarta: Pusat Stu di Wa nita UIN Syarif Hidayatullah Jakarta, 2005), h. 16
} 
menuntut hak dan mempertahankannya sebagaimana tercermin pada Q.s. al-Syura [42]:39-43.

Ummu Salamah r.a. menuturkan : "Dua orang laki-laki yang sedang bersengketa datang menghadap kepada Rasulullah Saw. untuk memohon keputusan hukum berkenaan dengan masalah pembagian waris yang telah lewat waktunya dan pada mereka tidak ada lagi bukti. Maka Rasulullah Saw. bersabda kepada dua orang yang bersengketa itu, "Kamu bertengkar dan menghadap kepadaku, sedangkan aku tidak lain adalah seorang manusia. Boleh jadi salah seorang dari kamu lebih lancar mengemukakan argumennya dari yang lain. Dan aku tidak bisa tidak akan memberi keputusan hukum di antara kamu sesuai dengan apa yang aku dengar (dari kamu). Maka jika telah kuputuskan untuk seorang di antara kamu agar ia berhak atas sebagian dari hak saudaranya, hendaklah ia jangan mengambilnya. Aku hanyalah hendak menyingkirkan seberkas api neraka yang akan dibawanya sebagai beban di tengkuknya pada hari kiamat”. Maka kedua orang laki-laki itu menangis, dan masing-masing keduanya berkata kepada yang lain, "Hakku (atas harta warisan itu) keberikan kepada saudaraku". Maka Rasulullah pun Saw. bersabda kepada mereka, "Jika kamu berdua telah mengatakan begitu, maka pergilah, dan berbagilah di antara kamu berdua (tentang harta warisan itu), kemudian hendaklah kamu berdua sama-sama melepaskan hak (atas harta itu), kemudian undilah di antara kamu berdua, lalu masing-masing dari kamu hendaklah menghalalkan (merelakan) saudaranya (menguasai harta itu)." (H.r. Ahmad dan Abû Dâwud). ${ }^{17}$

Berdasarkan penjelasan di atas, syariah dan tasa-wuf atau hukum dan moralitas bersifat integral. Keduanya tidak dapat dipisahkan. Noel J. Coulson, guru besar hukum Islam The University of Chicago, menyatakan: "The Islamic shariah is, in our terminology, both a code of law and a code of morals. It is a comprehensive scheme of human behavior which derives from the one ultimate authority of the will of Allah; so that the dividing line between law and morality is by no means so clearly drawn as it is in Western societies generally".

Dijelaskan bahwa integrasi antara syariat dan tasawuf atau hukum dan moralitas merupakan prinsip hidup seorang Muslim berdasarkan bimbingan Alquran dan Sunah. Keseimbangan diantara orientasi hukum dan moralitas merupakan prinsip penting di dalam Islam.

\footnotetext{
${ }^{17}$ Ha dis ini diriwayatkan Ahmad bin Hanbal dalam Kitab Musnad dan Abu Dawud dalam Kitab Sunan Abu Da wud. Muhib al-Din al-Khatib, kata penutup dalam, Abu Abdullah Muhammadibn Utsman alDza habi, Al-Muntaqa min Minhaj al-I’tidal, (ringka san Minhaj al-Sunnah karya Ibn Taymiyyah), (Damaskus: Maktbah Dar al-Bayan, 1374 H), h. 574
} 


\section{MENGENAL SOSOK SYAIKH ABDUL QADIR AL-JAILANI}

Al-Jailani mempunyai nama asli yaitu Abu Muhammad Muhyiddin Abdul Qadir Al-Jailani, beliau lahir di Naif di kawasan Jilan atau Kailan ${ }^{18}$ pada bulan Ramadhan di tahun $471 \mathrm{H}$. Sementara ada yang berpendapat bahwa al-Jailani lahir pada tahun $470 \mathrm{H} / 1077 \mathrm{M}$ dan meninggal pada tanggal 11 Rabi'ul Akhir tahun 561 H/1 166 M di usia 91 tahun di daerah Bab Al-Ajaz, Baghdad. ${ }^{19}$ Sepengamatan penulis, pendapat yang terakhirlah yang banyak diikuti oleh para pengamat biografi al-Jailani. Kemudian beliau juga mempunyai nasab yang panjang sampai bertemu dengan Rasulullah saw.

Berikut silsilah nasab beliau, nama ayah al-Jailani Abi Shalih Musa Junkai Dausat bin Abdillah bin Yahya Az-Zahid bin Muhammad bin Dawud bin Musa bin Abdillah bin Musa al-Juni bin Abdullah Mahdhi bin Hasan Mutsanna bin Hasan bin Ali bin Abi Thalib. ${ }^{20}$ Dan dari ibu bernama Fatimah binti Abdillah bin Mahmud bin Abi al-Atha bin Kamaluddin bin Abi Abdillah Alauddin bin Ali Ridha bin Musa al Kazim bin Ja'far al-Shadiq bin Muhammad al-Baqir bin Zain al-Abidin bin Husain bin Ali bin Abu Thalib. ${ }^{21}$ Silsilah kedua orang tuanya bersambung kepada baginda Rasulullah saw, dan banyak yang menyebutkan sebagai silsilah rantai emas. ${ }^{22}$ Sebagaimana kesepakatan itu dirangkum oleh cucu al-Jailani yaitu Muhammad Fadil, sekaligus penyunting tafsir Al-Jailani. ${ }^{23}$ Dalam perspektif sufistik al-Jailani merupakan sosok yang diagungkan dan menjadi ikon para wali sultan al-Auliya, alQutb al-Rabbani, al-Ghauts ${ }^{24}$, al-Baz al-Ashab dan lain-lain. ${ }^{25}$ Dan semuanya itu

\footnotetext{
${ }^{18}$ Kota itu berada di Thabaristan, dan bukan kota yang besar melainkan perkampungan kecil dia ntara pegunungan, Iran.

${ }^{19}$ AbdulQa dir Al-Jailani, al-Fathar-Rabbany wa al-Faidh ar-Rahmany (Kairo:Dar ar-Rayyan li atTurats, tt), h. 5. Bisa dilihat dalam kitab Sirral-Asrar wa Madhhar al-Anwar, Ka iro: Mathba'ah a 1Mishriyah h.19 dan dalam kitab al-Ghunyah li ThalibThariqal-Haqq, Vol. II, Beirut: Daral-Ihya atTurats al-'Arab, 1996, h. 17

${ }^{20}$ AbdulQa dir Al-Jailani, al-Fath ar-Rabbany wa al-Faidh ar-Rahmany (Kairo:Dar ar-Rayyan li at Turats, tt), h. 5 bisa dilihat dalamkitab Futuhul Ghoib, maktabah wa matba'ah mushtofa al-Yabi, tt h. 3 dan kitab Tafsir Al-Jailani, Dar al-Kotob al-Ilmiyah, Beirut, 2014, h. 5

${ }^{21}$ AbdulQa dir Al-Jailani, Sirr al-Asrar wa Madhhar al-Anwar, Ka iro: Mathba'ah al-Mishriyah, h.3

${ }^{22}$ Abdul al-Razaq al-Kaylani, al-Syaikh Abdul Qadir Al-Jailani : al-Imam al-Zahid al-Qudwah (Damaskus: Dar al-Qalam, 1994), h. 88

${ }^{23}$ Muhammad Fadil Al-Jailani, Nahral-Qadiriyah (Istanbul: Markaz Al-Jailani li al-Buhuts al-Ilmiyah, 2009), cet. 1 h. 67

${ }^{24}$ Da lam terminologikaum sufi, kata ghauts menduduki maqam dan keistimewaan ked ua dalam hal memohon ampun dan ridho Allah bagi umat manusia setelah Nabi.

${ }^{25}$ Muhammad Fadil Al-Jailani, Nahr al-Qadiriyah (Istanbul: Markaz Al-Jailani li al-Buhuts al-Ilmiyah, 2009), cet.2h. 73
} 
merupakan gelar dari al-Jailani karena mempunyai keistimewaan yang luar biasa dibandingkan dengan ulama-ulama lain.

Sejak kecil beliau sudah ditinggal ayahnya. Dan diasuh oleh sang kakek dari pihak ibu, Abdullah Assumu'i. Al-Jailani memiliki adik laki-laki bernama Abdullah, seorang anak yang shaleh dan meninggal ketika masih remaja. Al-Jailani dilahirkan ketika ibunya sudah berusia 60 tahun. Kewalian sudah tampak dimasa ketika beliau masih bayi, yaitu dengan tidak mau menyusui ibunya di siang hari pada bulan Ramadhan. Sehingga pernah pada suatu hari masyarakat dalam menentukan buka puasa mengikuti al-Jailani pada waktu masih kecil. Beliau terdidik dalam lingkungan besar lagi mulia, sesuai dengan nasab dan keturunan beliau. Beliau digembleng dalam didikan kaum sufi yang hidup serba sederhana dan ikhlas, dan mengutamakan akhirat. Kesibukan al-Jailani dalam upaya ruhaniah membuatnya asyik dan hampir lupa akan kewajibannya untuk berumah tangga. ${ }^{26}$

Di usia delapan belas tahun, beliau merantau ke Baghdad pada tahun $488 \mathrm{H}$ abad ke-5 $\mathrm{H}$ dimana kota itu merupakan pusat peradaban dan pengetahuan Islam yang paling maju. Al-Jailani terobsesi menuntut ilmu ke Baghdad karena merupakan tempat Imam bin Hambal, seorang sosok yang sangat dikagumi oleh penduduk Jilan. Pada saat bersamaan tahun tersebut al-Ghazali meninggalkan pengajaran di madrasah al-Nizamiyah kemudian mengasingkan diri di Syam, Baghdad. Sejauh peman dangan penulis, Al-Jailani hidup sezaman dengan al-Ghazali, namun tidak ditemukan bahwa al-Jailani berguru kepada al-Ghazali. Selain itu ada beberapa Ulama yang hidup sezaman al-Jailani seperti imam Ibnu al-Jauzy, Ibnu Qudamah, Syaikh Abu Umar ibn Shalah, Umar Khayam, al-Qusyairi, Az-Zuzani. ${ }^{27}$

Karena sifatnya yang sangat jujur dan murah hati, al-Jailani harus menjalani tirakat-tirakatnya dalam menuntut ilmu, sering berpuasa dan tak mau meminta makanan dari seseorang meski harus pergi berhari-hari tanpa makanan. Dalam masa pencarian inilah al-Jailani bertemu dengan Hadhrat Hammad bin Muslim al-Dibbas ${ }^{28}$ seorang penjual sirup, yang merupakan wali besar di zamannya. Lambat laun, menjadi

\footnotetext{
${ }^{26}$ AbdulQa dir Al-Jaila ni, al-Ghunyah li Thalib Thariqal-Haqq, Vol. II, Beirut: Dar al-Ihya at-Turats al-'Arab, 1996.h.17

${ }^{27}$ Abdul al-Razaq al-Kaylani, al-Syaikh Abdul Qadir Al-Jailani: al-Imam al-Zahid al-Qudwah (Damaskus: Dar al-Qalam, 1994), h.99

${ }^{28}$ Hadrat Hammad bin Muslim al-Dibbas nantinya akan jadi guru spiritual dalam bidang ta sawufnya alJailani.
} 
pembimbing rohani al-Jailani. Hadrat Hammad merupakan wali yang keras, sehingga sampai pada sebelas tahun al-Jailani menutup diri dari dunia. Dan diakhir masa ini berakhirlah masa latihan ruhaniyahnya sehingga al-Jailani menerima nur yang dicarinya. 29

Selain itu beliau juga belajar berbagai disiplin ilmu dibidang fikih berguru kepada Abu al-Wafa Ali bin Aqil al-Hambali dan Abu al-Khithab Mahfudz bin Ahmad al-Khalwadzani al-Hambali. Bidang ilmu sastra berguru kepada Abu Zakariya Yahya al-Tibrizi. Bidang ilmu Hadis berguru kepada Abu Ghain al-Baqilani, Ibnu Khunais, Abu Hanaim al-Rasi, Abu Bakar al-Tamara dan Abu Muhammad Al-Sirraj. Bidang tafsir dan Ilmu Al-Qur'an berguru kepada Abu al-Wafa Ali bin Aqil, Abu alKhitab Mahfudz al-Khalwadzani, Abu Ghanaim, Abdul al-Rahman bin Ahmad bin Yusuf, Abu al-Barakat Hibbatullah al-Mubarak dan lain-lain. ${ }^{30}$ Sedangkan al-Jailani belajar sufisme kepada Hammad bin Muslim al-Dibbas sebagaimana juga diafirmasi oleh Ibnu al-Immad. Terkait ketekunan yang luar biasa ini, Ibnu Taimiyyah menyatakan bahwa al-Jailani dan gurunya Hammad bin Muslim al-Dibbas adalah ahli istiqamah. ${ }^{31}$

Dalam beberapa keterangan sejarah, fikih madzhab Hambali dan Syafi'i merupakan ilmu yang paling ditekuni oleh al-Jailani. Setelah menguasai ilmu fikih, al-Jailani kemudian melengkapinya dengan tasawuf. Selepas itu juga al-Jailani mendapatkan ijazah dan kedudukan tinggi dari al-Qadhi Abu Said al-Mukhrami. Bahkan al-Jailani juga pernah belajar kepada Nabi Khidir a.s. selama tiga tahun. Satu tahun pertama beliau makan dan minum, tahun kedua hanya makan saja, dan di tahun ketiga beliau tidak makan dan tidak minum, hingga dinyatakan lulus belajarnya. ${ }^{32}$ Beliau juga mempunyai murid-murid yang banyak dan juga menjadi ulama' terkenal. Seperti Al Hafidz Abdul Ghani yang menyusun kitab Umdatul Ahkam Fi Kalami Khairil Anam. Juga Syeikh Qudamah penyusun kitab fiqh terkenal Al Mughni. ${ }^{33}$

\footnotetext{
${ }^{29}$ AbdulQa dir al-Jailani, Futuhul Ghoib Penyingkap keghaiban (Titah Surga: Yogyakarta, 2015), h.5

${ }^{30}$ AbdulRazaq, al-Kaylani, Abdul Qadir Jailani: al-Imam al-Zahid al-Qudwah, tt, h.102

${ }^{31}$ Anis Masduki, Metode Tafsir Sufistik Abdul Qa dir Al-Jailani(Yogyakarta: STIQ a n-Nur, 2010), cet.1.h.67

${ }^{32}$ AbdulQa dir Al-Jailani, Sirral-Asrarwa Madhhar al-Anwar Kairo: Mathba'ah al-Mishriyah, tt, h. 21

${ }_{33}$ AbdulQa dir Al-Jailani, Sirral-Asrar wa Madhhar al-Anwar, Kairo: Mathba'ah al-Mishriyah, tt, h. 23
} 
Setelah al-Jailani menamatkan pendidikannya di Baghdad, beliau mulai melancarkan dakwahnya. Tepatnya ketika beliau sudah berumur 50 tahun. Abu Said al-Mukhrami menyerahkan pembangunan madrasah kepadanya. Kian hari, muridmuridnya bertambah banyak. Karena itulah, madrasahnya diperluas dan pembangunannya selesai pada tahun $528 \mathrm{H}$ dimana pada saat itu beliau berumur 33 tahun. Di madrasah ini juga, al-Jailani berjuang dengan sungguh-sungguh dalam mengajarkan Islam. Sepeninggal al-Jailani para putra ${ }^{34}$ dan muridnya mendirikan suatu thariqah, untuk menyuburkan spiritualitas Islam di kalangan dunia, dan menamakan tarekat Qadiriyah yang sampai sekarang masih ada. ${ }^{35}$ Tarekat qadiriy ah selalu taat dengan prinsip syariatnya dan paling kredibel dari segi sanadnya, sehingga paling banyak diikuti oleh umat Islam sedunia. Berkaitan dengan tarekat ini, Ibnu Taimiyyah berkata: "Tarekat beliau adalah tarekatyang dibenarkan oleh Syara'. ${ }^{36}$ Sebagai penguat Martin menyebutkan, tarekat Qadiriyah muncul setelah beberapa generasi kemudian, meskipun demikian akan sangat mungkin al-Jailani mempunyai ajaran yang khusus yang tidak disebarkan, kecuali kepada murid-murid terdekatny a saja. ${ }^{37}$ Sebagaimana tarekat yang lain tarekat tersebut ajarannya lebih cenderung kepada pengembangan diri dalam mendekatkan diri kepada Sang pencipta melalui beberapa tahapan-tahapan pembersihan hati. Karakter tarekat ini lebih kalem daripada tarekat yang lain. Kalem dalam arti orang-orang yang menganut tarekat tersebut kebanyakan lebih halus dan teratur ajarannya. Berbeda dengan tarekat Syadiliyah yang lebih menggunakan dunia sebagai alat untuk pengembangan diri dalam mendekatkan diri dengan Sang Pencipta.

Perlu diketahui juga bahwa, selain akhirnya membuahkan atsar tarekat Qadiriyah yang bersifat kalem, al-Jailani juga memiliki karya-karya sebagai penopang ajaran-ajarannya. Di antara karya yang terkenal adalah; al-Ghunyah li Thalib Thariq al-Haqq, kitab ini memaparkan secara ringkas fikih mazhab Imam Hambali dan ajaran-ajarannya tentang akidah dan tasawuf; al-Fath ar-Rabbani, kitab ini berisi kumpulan nasihat bagi para murid dan guru sufi dan semua kalangan yang tertarik

\footnotetext{
${ }^{34}$ Abdul Wahhab (w.593 H), Abdul Razaq (w.603), Abdus Salam (w.611 H)

${ }^{35}$ Abdulal-Razaq al-kaylani, al-Syaikh Abdul Qadir al-Jailani: Imamal-Zahidal-Qudwah, h.127

${ }^{36}$ AbdulQa dir Al-Jailani, Sirral-Asrar wa Madhhar al-Anwar Kairo: Mathba'ah al-Mishriyah, tt, h. 28

${ }^{37}$ Martin Van Bruinessen, Kitab Kuning, Pesantren dan Tarekat (Gading Publishing: Yogyakarta, 2015)h. 260
} 
dengan jalan penyucian diri. Sesuai dengan judulnya, kitab ini hendak membawa pembacanya pada keuntungan dan manfaat spiritual yang sangat besar; dan Futuh alGhaib yang berisi kumpulan nasihat yang lebih lengkap dan mendalam dari kumpulan sebelumnya. Kitab yang lain yaitu Tafsir al-Jailani, ad-Diwan, Sirrul Asrar, Gunyah Li Thalibi Thariqil Haq, Assafinatu al-Qadiriyah, At-Thariqu Ilallah al-Jailani,Adabu as-Suluk al-Jailani, al Auradu al-Qadiriyah, manaqib an-Nurul Burhan, Manaqib Jawahirul Ma'ani, dan masih ada kitab-kitab lain yang menceritakan tentang manusia mulia as-Syaikh Abdul Qadir al-Jailani. Kitab-kitab tersebut ditulis oleh para murid murid Sang wali Qutub yang sangat mencintai kepribadian al-Jailani, sosok yang mempunyai karamah tinggi dan alim tentunya.

\section{KONDISI SOSIAL POLITIK DI MASA ABDUL QADIR AL-JAILANI}

Al-Jailani merupakan seorang tokoh spiritual yang lahir pada pertengahan masa daulah Abbasiyah IV atau Bani Saljuk pada tahun 477-590H/1084-1197 M. ${ }^{38}$ Kondisi saat itu tengah dilanda pergolakan baik dari luar maupun dari luar dan persaingan ideologis yang hebat, sehingga mengakibatkan dehumanisasi, despiritualisasi dan destrukturalisasi. Namun al-Jailani tumbuh dalam lingkungan yang penuh dengan kemajuan baik ilmu pengetahuan, intelektualitas maupun kemasyarakatan.

Masa Daulah Abbasiyah pada masa itu didampingi oleh dinasti Bani Saljuk (Turki II), bahkan dinasti Saljuk banyak berperan dan mewarnai Daulah Abbasiyah IV. Hal seperti ini juga terjadi pada kekuasaan Bani Buwaih keturunan Syia'ah Imamiyah Iran tahun 334-447 H/945-1055 M yang mendampingi kekuasaan Daulah Abbasiyah di kota yang sama (Baghdad). Masa Daulah Abbasiyah IV diwarnai dengan dua corak kepemimpinan yaitu corak kekhalifahan yang kekuasaannya dipegang oleh keturunan Abbasiyah dan corak kesultanan yang kekuasaannya dipegang oleh keturunan Saljuk. Ada perbedaan antara Bani Buwaih dengan Bani Saljuk dalam hal dominasi kekuasaan. Pada masa Bani Buwaih, khalifah sama sekali digeser peranannya, tetapi pada masa Saljuk, khalifah masih mendapat kehormatan. Hal ini bisa dibuktikan dengan adanya hak legitimasi khalifah terhadap sultan. ${ }^{39}$

\footnotetext{
${ }^{38}$ Ahmad Kamaluddin Hilmi, As-Salajiqahfi at-Tarikh waal-Hadharah (Kuwait:Dar a l-Buhuts alIlmiah, 1975), hlm.197

${ }^{39}$ Ahmad Kamaluddin Hilmi, As-Salajiqahfi at-Tarikh waal-Hadharah (Kuwait:Da r a l-Buhuts alIlmiah, 1975), hlm.198
} 
Ahmad Kamaluddin Hilmi menyebutkan bahwa masa pemerintahan Saljuk yaitu pada masa Izz al-Muluk bin Nizham al-Muluk, masa wazir Barkyaruk negara ditandai dengan kezaliman dan kemerosotan moral. Mereka terbius dengan kemewahan duniawi, berfoya-foya, mabuk-mabukkan, menumpuk harta dan budak. Hal ini sebagaimana pula yang disebutkan oleh Ali bin Abi Ali al-Qumi dalam Diwan al-Istiwa bahwa masa itu ditandai dengan kesuraman. ${ }^{40}$

Dengan kondisi tersebut, banyak kalangan dari orang terkenal yang lari mengasingkan diri dan bertasawuf dalam hidupnya karena merasa prihatin. Sehingga dari kenyataan ini tasawuf hidup dengan subur. Tokoh-tokoh sufi yang bermunculan pada masa itu adalah al-Ghazali, Abdul Qadir al-Jailani walaupun belum ditemukan al-Jailani berguru kepada al-Gazhali namun hidup mereka sezaman. Kemudian alAnwari, As-Sinai, dan Dahiruddin al-Faryabi. ${ }^{41}$

Dengan demikian Al-Jailani hidup dimasa pertengahan Daulah Abbasiyah ${ }^{42}$ yang dalam masa pergolakan krisis politik baik dari dalam ${ }^{43}$ maupun luar ${ }^{44}$. Selain itu ditandai dengan kezaliman dan kemerosotan moral dari para penguasa dan masyarakat. Masyarakat Baghdad terbius dengan kemewahan duniawi, berfoya-foya, bermabuk-mabukkan, menumpuk harta dan budak $^{45}$. Keadaan seperti itu tidak sebanding dengan keadaan keramaian intelektual dan megahnya peradaban di Baghdad pada masa itu. Dikarenakan kota itu sebagai pusat pendidikan dan menjadi sentral peradaban untuk menuntut ilmu. 46

Kondisi seperti inilah yang dihadapi oleh al-Jailani semasa hidupnya. Situasi ini diantaranya yang mendorong al-Jailani untuk menjadi petunjuk jalan kebenaran,

\footnotetext{
${ }^{40}$ Ahmad Kamaluddin Hilmi, As-Salajiqahfi at-Tarikh waal-Hadharah (Kuwait:Da r a l-Buhuts alIlmiah, 1975), hlm.200

${ }^{41}$ AbulHasan an-Nadwi, Rijal al-Fikri wa ad-Dakwah fi al-Islam (Ku wa it: Da r a 1-Qalam, 1969), hlm.237

${ }^{42}$ Masa daulah ini di pimpin oleh dua corak kepemimpinan yang berbeda yaitu co rak kekhalifahan dipimpin oleh keturunan Abbasiyah, da n corak kesultanan dipimpin oleh keturunan Saljuk.

${ }^{43}$ Contohnya a danya gerakan teroris, sejumlah komplotan tentara y ang tidak puas dengan kebijaksa an pemimpin, kemudian 7000 tentara di pecat dianggap tidak disiplin.

${ }^{44}$ Misalnya perang salib sela matiga a bad la manya tahun 1029-1270 M. Umat Is lam pa da waktu itu mera sa kesulitan menghadapi tentara y ang begitu rapi karena mereka disibukkan menghadapi keributan ma salah intern.

${ }^{45}$ Ahmad Kamaluddin Hilmi, As-Salajiqahfi-at Tarikh wa al-Hadharah (Kuwait:Dar Al-B uhuts a 1Ilmiah, 1975), h. 200.

${ }^{46}$ AbdulRa zaq, al-Kaylani, Abdul Qadir Jailani: al-Imamal-Zahid al-Qudwah, tt h.105
}

Halaman $1-28$ 
berdakwah, mengajar, dan bertekad memperbaharui jiwa-jiwa yang rusak, memerangi kemunafikan, dan memadamkan bara api perpecahan ${ }^{47}$.

Dengan kondisi tersebut banyak orang terkenal lari dan mengasingkan diri untuk bertasawuf karena merasa prihatin. Sehingga dengan adanya kenyataan ini tasawuf hidup subur. Tokoh-tokoh sufi yang bermunculan: Imam al-Ghazali, Syaikh Abdul Qadir al-Jailani, al-Anwari, As-Sina'i, dan Dahiruddin al-Faryabi. ${ }^{48}$ Al-Jailani tampil untuk menyelamatkan kemerosotan akhlak yang terjadi di masa itu dan melakukan upaya tabayun konsepsi akidah.

Sebagian ulama salaf seperti Imam Sya'rani menilai bahwa al-Jailani mengkompromikan madzhab Hambali dan Syafi'i dalam ilmu fikih. ${ }^{49}$ Madzhab Hambali yang dianggap skriptual ternyata bisa sinergis dalam sufisme menerima cahaya kebenaran. Ada yang berpendapat bahwa keteguhan al-Jailani dalam madzhab Hambali ini untuk mempertahankannya dari kepunahan. Hal ini dibuktikan oleh salah satu muridnya, Ibnu Qudamah yang kemudian mempunyai peranan besar dalam melestarikan Madzhab Hambali ${ }^{50} \mathrm{Hal}$ ini membuktikan bahwa ajaran tasawuf alJailani bersifat universal dan toleran dalam interaksi antara Tuhan dengan manusia, sehingga menjadi pedoman pemahaman inter-religi.

\section{PANDANGAN AKIDAH ABDUL QADIR AL-JAILANI}

Untuk menyelamatkan kemerosotan akhlak yang terjadi di masa itu, al-Jailani berusaha melakukan upaya tabayun konsepsi akidah dalam hal ini yang dilakukanny a adalah bertasawuf. Tasawuf dalam pandangan al-Jailani adalah integrasi keilmuan yang berlandaskan al-Quran dan Hadits serta konsistensi pengamalan ajaran Islam dengan menjernihkan jiwa dan pikiran melalui pembersihan hati. Yaitu dengan cara mengaktualisasikan diri menyembah kepada Allah dengan sungguh-sungguh dan memiliki akhlak yang terpuji ketika berinteraksi dengan manusia. ${ }^{51}$ Ciri khas sufisme al-Jailani adalah mengatur dua dimensi rasional, pertama; secara vertikal hubungan manusia dengan Tuhan dalam bentuk ibadah, kedua; hubungan horizontal sesama

\footnotetext{
${ }^{47}$ Ahmad Kamaluddin Hilmi, As-Salajiqahfi at-Tarikh wa al-Hadharah (Kuwait:Da r a 1-Buhuts alIlmiah, 1975), hlm.198

${ }^{48}$ Abu Ha san An-Nadwi, Rijal Al-Fikri wa Ad-Dakwah fi Al-Islam (Kuwait Dar Al-Qala m, 1969), h. 237.

${ }^{49}$ Al-Sha'rani, Tabaqatal-Kubra (Kairo:Dar al-Fikr al-Arabi,tt), h. 109

${ }^{50}$ Abdulal-Razaq al-kaylani, al-Syaikh Abdul Qadir al-Jailani: Imamal-Zahidal-Qudwah,tt h.126

${ }^{51}$ Muhammad Fadil al-Jailani, Nahral-Qadiriyah (Istanbul: Markazal-Jailanili al-Buhuts al-Ilmiyah, 2010), cet.1.h. 185
} 
manusia sebagai makhluk sosial dalam berinteraksi. Dengan demikian paradigma sufistik al-Jailani adalah integrasi ilmu dan amal.

Al-Jailani menjelaskan ada beberapa tingkatan iman. Beliau memberikan uraian derajat iman terdapat dalam beberapa tingkatan: (1) keyakinan (2) keikhlasan (3) menunaikan kewajiban (4) menyempurnakan ibadah sunnah (5)menjaga akhlak dalam segala aspek ibadah dan muamalah. ${ }^{52}$ Aspek yang terakhir merupakan aspek yang paling penting dan disebut sebagai benteng pertahanan, karen a bagaiman apun juga syetan dengan segala cara bisa menggoda manusia untuk menembus benteng pertahananan tersebut. Oleh karena itu jika tidak dijaga akhlak seseorang maka syetan akan mampu menembus ke level yang diatasnya yaitu kewajiban, keihklasan dan keyakinan. Dan merupakan benteng terakhir sehingga mengakibatkan hilangnya keimanan seseorang.

Oleh karena itu merupakan kewajiban bersufi untuk bisa menjaga adab-a dab syariah agar bisa mencapai pengetahuan yang layak di hadapan Tuhan serta mendapatkan hakikat dan makrifat akan keberadaan Tuhan Sang Pencipta Alam Raya. Hal ini hanya bisa dilakukan melalui pekerjaan hati. Mengingat tempat bersemay am iman ada di hati. Dengan pemantapan adab ini, berarti akan menyinari keislaman secara lahir dan batin. ${ }^{53}$

Dalam melancarkan dakwah Islam, al-Jailani lebih menitik beratkan kepada Iman seseorang untuk selalu mentauhidkan Allah. Karena Iman merupakan tolak ukur setiap individu yang mengaku sebagai seorang muslim. Oleh karena itu, iman memerlukan pengakuan secara konkrit dari seorang muslim atas ketentuan yang berlaku menurut syariat Allah. Al-Jailani berkata:

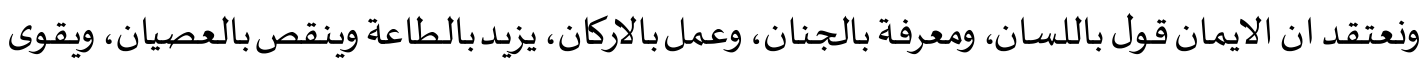

$$
\text { بالعلم ويضعف بالجهل، وبالتوفيق يقع }
$$

\footnotetext{
${ }^{52}$ AbdulQa diral-Jailani, al-Ghunyah li Thalib Thariqal-Haqq, Vol. I (Beirut: Dar al-Ihya at-Turats al'Arab, 1996), h. 149, penulis mengutip dari sebuah desertasi Aik Iksan Anshori, denganju dul Tafsir Ishari Pendekatan Hermeneutika Sufistik Tafsir Abdul Qadir al-Jailani, Ciputat:2012.h.117

${ }^{53}$ AbdulQa dir al-Jailani, al-Ghunyah li Thalib Thariqal-Haqq, Vol. I (Beirut: Dar al-Ihya at-Turats al'Arab, 1996), h. 150
} 
Iman adalah ucapan dengan lisan, keyakinan dalam hati, dan perbuatan dengan anggota badan. Iman akan menjadi kuat dengan ilmu dan akan menjadi lemah dengan kebodohan, dan semua itu akan terjadi dengan pertolongan Allah. ${ }^{54}$

Menurut al-Jailani pencarian ma'rifat harus bertumpu pada keimanan yang menjadi keyakinan (haqqal-yaqin), sehingga dari keyakinan itu muncul ma'rifat, dan kemudian ma'rifat inilah yang akan muncul sebagai ilmu yang menyebabkan cerdas di sisi Allah Swt. Hal ini merupakan salah satu arti ma'rifat menurut Syaikh Abdul Qadir, dimana seseorang tidak lagi menyekutukan Allah Swt dengan makhluk, a mal, ataupun keinginannya. Keesaan Allah Swt benar-benar dijunjung tinggi, tempat bergantung seluruh makhluknya, tidak ada yang menyamai-Nya (sifat dan dzat-Nya), dan tidak bisa diterka-terka. ${ }^{55}$

Dalam konsepsinya pemurnian tauhid dan penafian syirik, al-Jailani mempunyai pandangan yang mendalam. Menurutnya kesyirikan tidak hanya penyembahan pada berhala saja, tetapi juga pada pemujaan nafsu jasmani dan menyamakan segala sesuatu yang ada di dunia dan akhirat dengan Allah. Sebab selain Allah bukan Tuhan, dan menenggelamkan diri pada sesuatu selain Allah berarti menyekutukan Tuhan. Hidup bermewah-mewahan dan menyibukan diri dengan kehidupan dunia karena beranggapan bahwa kebahagiaan akan didapat di dala mnya, berarti juga menyekutukan Tuhan. Al-Jailani juga menyebutkan bahwa syirik orang khawas (kebalikan awam,) adalah menyekutukan kehendaknya dengan kehendak Allah, yaitu lalai dan terbawa suasana dunia. ${ }^{56}$

Al-Jailani adalah seorang sunni yang dalam banyak hal berbeda pandangan dengan aliran-aliran pemikiran yang berkembang di semasa hidupnya. Secara keseluruhan, metode yang dipakai oleh al-Jailani dalam menetapkan akidahnya adalah menggunakan Manhaj Turatsi, yang berafilisasi kepada manhaj ulama salaf shalih. Dalam permasalahan "usaha manusia" (af'al al- 'ibad) misalnya, ia berbeda dengan pandangan Jabariyah yang fatalis dan Qadariyah. Menurutnya, perbuatan hamba itu adalah ciptaan Allah swt, demikian pula usaha mereka yang baik maupun yang buruk,

\footnotetext{
${ }^{54}$ AbdulQa diral-Jailani, al-Ghunyah li Thalib Thariqal-Haqq, Vol. I, (Beirut: Dar al-Ihya a t-Turats al-'Arab, 1996), h. 93

${ }^{55}$ AbdulQa dir al-Jailani, Futuhul Ghoib, (Maktabah wa Matba'ah Mushtofa:Mesir,1973), h.13

${ }^{56}$ AbdulQa dir Al-Ja ila ni, al-Ghunyah li Thalib Thariqal-Haqq, Vol.I, (Beirut: Daral-Ihya at-Turats al-'Arab, 1996), h. 42. Bisa dilihat pada kitab Futuhul Ghoib, h.17
} 
yang benar atau yang salah, yang taat atau yang maksiat. Namun bukan berarti bahwa Allah swt memerintahkan maksiat, tapi Allah swt telah menentukan dan menetapkan serta menjadikan sesuai dengan kehendaknya. Hanya saja sesuatu yang berkaitan dengan perintah dan larangan yang ditujukan kepadanya adalah usaha manusia ( $\mathrm{al}$ $k a s b)$. Jika balasan itu jatuh kepada manusia, jelaslah bahwa perbuatan itu karena usaha mereka. 57

Berbeda dengan Jabariyah, mereka berpendapat bahwa manusia tidak mampu untuk berbuat apa-apa, tidak mempunyai daya, tidak mempunyai kehendak sendiri, dan tidak mempunyai pilihan. Sedangkan pandangan al-Jailani juga berlawanan dengan kaum Qadariyah. Mereka menyatakan bahwa manusia berkuasa atas perbuatan-perbuatannya. Manusia sendirilah yang melakukan perbuatan baik atas kehendak dan kekuasaan sendiri dan manusia sendiri pula yang melakukan atau menjauhi perbuatan-perbuatan jahat atas kemauan dan dayanya sendiri. ${ }^{58}$

Jadi jelaslah di sini bahwa al-Jailani tidak menghendaki manusia pasrah pada nasib dan takdir Allah sebagaimana kaum Jabariyah. Juga tidak seperti Qadariyah yang menafikan peranan Allah dalam setiap perbuatan manusia. Oleh karena itu, alJailani menengahi di antara dua kutub pemikiran yang ekstrim tersebut. Dan al-Jailani menganjurkan kepada manusia untuk selalu berusaha dan berdoa. Jika takdir sudah tiba, manusia harus menerima (tawakal), oleh sebab itu Allah swt lebih mengetahui segala hikmah.

\section{KONSEP TASAWUF AL-JAILANI}

Tasawuf sering disebut sebagai misitsisme dalam Islam oleh orientalis. Terdapat berbagai kemungkinan mengenai asal-usul istilah tasawuf ini. Ada yang mengatakan berasal dari kata Suffah, nama suatu ruang dekat masjid Madinah, tempat Nabi Muhammad saw memberikan pelajaran kepada para sahabatnya seperti Abu Darda, Abu Hurairah, Abu Dzar al-Ghifari dan lain sebagainya. Ada juga yang mengatakan berasal dari kata suf yang berarti bulu domba, yang umumnya menjadi bahan pakaian orang-orang sufi dari Siria. Lainnya mengatakan, ia berasal dari kata shaafiy yang berarti suci, artinya seorang sufi adalah orang yang disucikan melalui

\footnotetext{
${ }^{57}$ AbdulQa dirbin Habibullah as-Sindi, at-Tashawuffi Mizanil Bahtsi wa Tahqiq, Da rul Manar, 1995, cet.II, h.509, juga bisa dilihat padakitab al-Ghunyah li Thalib Thariqal-Haqq, Vol. I, Beirut: Dar alIhya at-Turats al-'Arab, 1996, tt. h.64

${ }^{58}$ AbdulQadir al-Jailani, Futuhul Ghoib, (Maktabah wa Matba'ah Mushtofa:Mesir,1973), h.22
} 
latihan-latihan ibadah. Selain itu ada yang beranggapan dari kata sophos, kata Yunani yang berarti hikmah.

Menurut Al-Jailani dalam kitab Sir al-Asrar, Al-Jailani menguraikan makna sufi dan tasawufnya sesuai dengan huruf-hurufnya "Tasawuf”. 59

Huruf pertama adalah " $t a$ ” yang berarti taubah. Pintu taubat adalah selalu merasa khawatir tentang kedudukan dirinya di sisi Allah. Pengertian taubat di sini meliputi dua macam taubat yakni taubat lahir dan taubat batin. Yang dimaksud dengan taubat lahir adalah menyesuaikan perbuatan dan perkataannya dengan ketaatan kepada Allah dan Nabi-Nya. Sedangkan taubat batin sama artinya dengan tashfiyah al-qalb, penyucian hati dari sifat-sifat yang tercela, untuk kemudian diganti dengan sifat-sifat yang terpuji. Inti dari taubat adalah mengerahkan hati sepenuhnya untuk sampai kepada tujuan utamanya, yakni Allah al-Haq. ${ }^{60}$

Huruf kedua adalah "shad" yang berarti "shafa" yang berarti bersih dan bening. Makna shafa' disini juga meliputi dua macam shafa', yakni shafa' al-qalb dan shafa as-sirr. Maksud dari shafa' al-qalb adalah membersihkan hati dari sifatsifat manusiawi yang kotor dan kenikmatan dunia, seperti banyak makan dan minum, banyak tidur, banyak bicara yang tidak berguna, cinta harta, dan lain lain. Untuk membersihkan hati dari yang demikian itu, caranya adalah dengan memperbanyak dzikir kepada Allah dengan suara jahr (keras) sampai pada tingkatan takut. ${ }^{61}$ Sesuai dengan firman Allah:

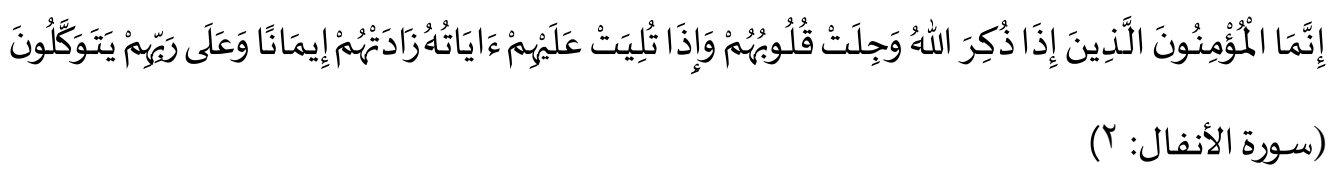

Artinya: "Sesungguhnya orang-orang yang beriman itu adalah mereka yang apabila disebut nama Allah gemetarlah hati mereka, dan apabila dibacakan kepada mereka Ayat-ayat-Nya, bertambahalah iman mereka (karenanya) dan kepada Rabblah mereka bertawakkal, (QS. al-Anfaal: 2)

\footnotetext{
${ }^{59}$ AbdulQa dir al-Jailani, Sirral-Asrar wa Madhharal-Anwar (Kairo: Mathba'ah a 1-Mishriy ah), tt. h.76

${ }^{60}$ AbdulQa dir al-Jailani, Sirral-Asrarwa Madhharal-Anwar (Kairo:Mathba'ah a 1-Mishriy ah), tt. h.77

${ }^{61}$ AbdulQadiral-Jailani, Sirral-Asrarwa Madhharal-Anwar(Kairo:Mathba'ah a 1-Mishriy ah, tt), h.77
} 
Sedangkan maksud dari shafa as-sirr adalah mencintai Allah dan menjauhi segala sesuatu selain Allah swt dengan cara senantiasa melantunkan asma' Allah melalui lisannya secara sirr. Apabila keduanya telah dilaksanakan dengan sempurna maka, sempurnalah maqam huruf 'shad' ini. ${ }^{62}$

Huruf ketiga adalah 'waw' yang bermakna wilayah. Yaitu keadaan suci dan hening yang ada pada jiwa kekasih Allah. Keadaan ini tergantung pada kesucian seseorang yang tercermin dalam QS. Yunus ayat 62:

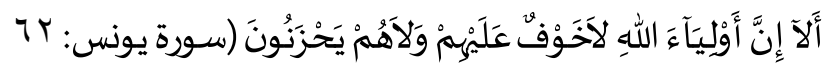

Artinya: "Ingatlah, sesungguhnya wali-wali Allah itu, tidak ada kekhawatiran terhadap mereka dan tidak (pula) mereka bersedih hati.” (QS. Yunus:62)

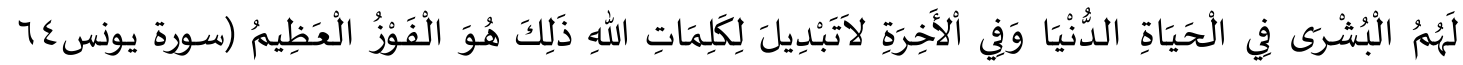
Artinya: "Bagi mereka berita gembira di dalam kehidupan di dunia dan (dalam kehidupan) di akhirat. Tidak ada perobahan bagi kalimat-kalimat (janji-janji) Allah. Yang demikian itu adalah kemenangan yang besar.” (QS. Yunus :64)

Orang yang sampai pada tahapan ini, mendapatkan kesadaran dan cinta sepenuhnya dari Allah, sehingga akhlaknya adalah akhlakNya. Dan segala tindak tanduknya bersesuaian dengan kehendakNya. ${ }^{63}$ Sebagaimana dalam hadits qudsi, Allah berkata: "Hamba-Ku yang beriman selalu mendekatkan diri dengan mengerjakan amalan-amalan yang diutamakan, sehingga Aku mencintainya, dan apabila Aku telah mencintainya, maka Aku menjadi telinganya, dengannya ia mendengar, dan menjadi matanya, dengannya ia melihat, dan menjadi tangannya, dengannya ia bekerja dan menjadi kakinya, dengannya ia berjalan. Tak diragukan lagi, beginilah fana'64

Huruf yang terakhir adalah ' $f a$ ' yang melambangkan fana' di dalam kebesaran Allah, yaitu pengosongan dan penghapusan segala macam sifat-sifat manusia dengan menyatakan keabadian sifat-sifat Allah. Terlepas diri dari makhluk dan kedirianya

\footnotetext{
${ }^{62}$ AbdulQa dir al-Jailani, Sirral-Asrarwa Madhharal-Anwar (Kairo: Mathba'aha l-Mishriy ah, tt) h. 78

${ }^{63}$ AbdulQadiral-Jailani, Sirral-Asrarwa Madhharal-Anwar (Kairo: Mathba'ah a 1-Mishriy ah, tt), h.78

${ }^{64}$ AbdulQadiral-Jailani, Futuhul Ghoib(Maktabah wa Matba'ah Mustofa: Mesir, 1973), h. 15
}

Vol. 7. No. 1. April 2021

Halaman $1-28$ 
serta sesuai dengan kehendak-Nya. Jika sudah demikian, maka ke-fana' -an manu sia akan abadi (baqa') bersama Tuhannya dan keridhaan-Nya. ${ }^{65}$

Pengertian fana' al-Jailani ini, jika disandingkan dengan pandangan Ibrahim Madkur ketika mengomentari istilah fana'-nya para sufi falsafi, sangat identik dengan pandangan mereka. Menurut Ibrahim Madkur, pada dasarnya teori fana yang didengungkan oleh para sufi akhirnya hendak menjelaskan tentang hilangnya kesadaran dan perasaan pada diri dan alam sekitar, terhapusnya seorang hamba dalam kebesaran Tuhan, sirnanya seorang hamba terhadap wujud dirinya dan kekal di dalam wujud Tuhannya setelah melewati perjuangan dan kesabaran serta pembersihan jiwa. Untuk menjelaskan keabadian seorang hamba, al-Jailani lebih hati-hati agar tidak disalah pahami. Menurutnya, keabadian manusia, disebabkan amal shalihnya. ${ }^{66}$

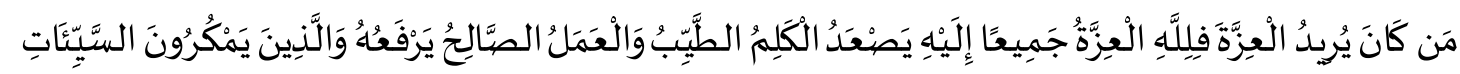

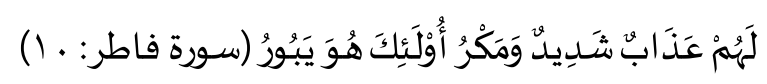

Artinya: "Barangsiapa yang menghendaki kemuliaan, maka bagi Allah kemuliaan itu semuanya.Kepada-Nyalah naik perkataan-perkataan yang baik dan amal yang saleh dinaikkan-Nya.Dan orang-orang yang merencanakan kejahatan bagi mereka azab yang keras, dan rencana jahat mereka akan hancur. ”(QS. Fathir:10)

Meskipun al-Jailani tidak mensistematisasikan tasawufnya dalam bentuk maqamat-maqamat atau ahwal-ahwal secara berurutan seperti kebanyakan sufi, namun ketika melihat dari ulasan al-Jailani tentang pengertian tasawuf secara harfiah, telah mengarahkan perjalanan ruhani seseorang dalam untuk melewati tahap-tahap tertentu, mulai dari taubat dengan macam-macamnya, pembersihan hati dengan macam-macamnya, yang berakhir pada tingkatan fana' ${ }^{67}$

Jika dikatakan bahwa memilih hidup sufi berarti memilih hidup dengan menjauhi dunia, maka sekali-kali al-Jailani tidak pernah mempunyai sikap hidup mengasingkan diri dalam arti membenci dunia meski ia menolak untuk menikmati keinginan-keinginannya yang menenggelamkan dan mengasyikkan hati, sehingga

\footnotetext{
${ }^{65}$ AbdulQa dir al-Jailani, Sirral-Asrar wa Madhhar al-Anwar (Kairo: Mathba'ah a l-Mishriy ah, tt. h.79

${ }^{66}$ Ibrahim Madkur, Fi Falsafah Islamiyah Manhaj wa Tathbiquhu (Kairo: Dar al-Ma'arif, 1976), 25

${ }^{67}$ AbdulQadiral-Jailani, Futuhul Ghoib(Maktabah wa Matba'ah Mustofa:Mesir, 1973), h. 13
} 
membuat lupa kepada penciptanya. Mengenai permasalahan ini al-Jailani juga berkata dalam kitab futuhul ghoib:

"Kuasai dunia, jangan dikuasai olehnya. Milikilah dunia, jangan dimiliki dunia. Setirlah dunia, jangan diperbudak olehnya. Ceraikanlah dunia, jan gan kamu diceraikan olehnya. Jangan kamu dibinasakan olehnya. Tasarufkanlah dunia, karena sabda Nabi: Sebaik-baik harta adalah harta hamba yang saleh ${ }^{68}$.

Al-Jailani mengibaratkan dunia bagai sungai besar yang deras airnya, setiap harinya bertambah. Dan perumpamaan nafsu hewani manusia juga tidak ubahnya seperti sungai itu, yang tamak akan segala kenikmatan duniawi. Ia memandang kehidupan yang sejati adalah kehidupan di kemudian hari, yaitu akhirat. Sesuai dengan sabda Nabi: “Tidak ada kehidupan selain kehidupan akhirat nanti. Dan dunia adalah penjara bagi orang-orang mukmin dan surga bagi orang-orang kafir. ” 69

Dunia dipandang olehnya sebagai proses kontinuitas kehidupan akhirat yang keduanya tidak bisa dipisahkan. Sufisme dalam pandangan al-Jailani merupakan sufisme yang progresif, aktif dan positif, tidak meninggalkan gelanggang dunia sebagai mazra'ah al-akhirah. Ia memandang dunia dalam keseimbangan akhirat.

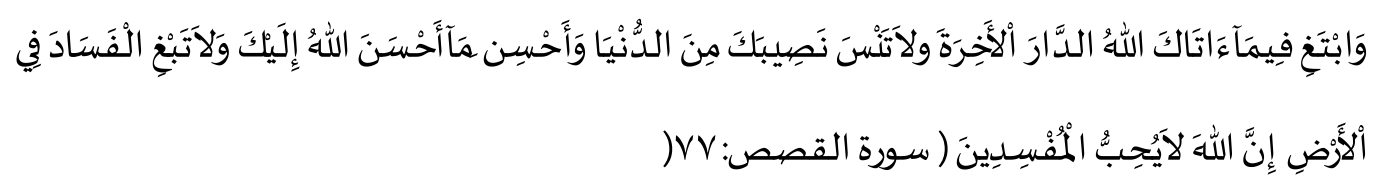

Artinya: "Dan carilah pada apa yang telah dianugerahkan Allah kepadamu (kebahagiaan) negeri akhirat, dan janganlah kamu melupakan bahagianmu dari (kenikmatan) duniawi dan berbuat baiklah (kepada orang lain) sebagaimana Allah telah berbuat baik kepadamu, danjanganlah kamu berbuat kerusakan di (muka) bumi.Sesungguhnya Allah tidak menyukai orang-orang yang berbuat kerusakan. (QS. 28:77)

Beliau berhasil memadukan antara syariat dan sufisme secara praktis-aplikatif. Al-Jailani meniscayakan syariat sebagai syarat mutlak untuk meraih keselamatan di dunia dan akhirat, dan kunci penting untuk sampai pada kedekatan dengan-Nya.

\footnotetext{
${ }^{68}$ Abdul Qadir al-Jailani, Futuhul Ghoib Penyingkap Keghaiban (Titah Surga: Yogyakarta, 2015), h. 129

${ }^{69}$ AbdulQa diral-Jailani, Futuhul Ghoib Penyingkap Keghaiban (Titah Surga: Yogyakarta, 2015), h. 128
} 
Beliau juga mengungkapkan bahwa ma'rifat harus dilalui dengan mujahadah dan pembersihan diri (tazkiyah al-nafs). ${ }^{70} \mathrm{Hal}$ di atas dapat diketahui dari konsep ma'rifat al-Jailani yaitu:

$$
\text { العرفوا اللة ولاتجهلوه، واطيعوالله ولاتعصيوه، ووافقوه ولاتخا لفوه وارضوا بقضيائه ولاتنازعوه، واعرفوا }
$$

"Kenali Allah Swt (ma'rifatullah) dan jangan sampai kalian tidak mengenalnya. Taatilah Allah SWT, dan jangan sampai kalian bermaksiat kepadaNya. Ikutilah (Petunjuk-Nya), dan janganlah kalian berlawanan dengan-Nya, Ridhailah keputusan-Nya, dan janganlah kalian menentang-Nya, Kenalilah Allah SWT melalui ciptaan-Nya, Dialah Yang Maha menciptakan dan Maha memberi rizki, Yang Paling Awal dan Yang Paling Akhir, Yang Paling Tampak dan Yang Paling Rahasia, Yang Paling Terdahulu dan Yang Paling Ada, serta Maha berbuat Terhadap sesuatu yang dikehendaki-Nya". ${ }^{71}$

Orang-orang ma'rifat menurut al-Jailani memiliki keikhlasan sempurna dala m ibadahnya dengan memberikan sifat ketuhanan dan pengabdian kepada-Nya sesuai dengan hak-Nya. Disini hak nafsu menjadi benar karena telah buta kepada dunia, akhirat, dan segala sesuatu selain Allah SWT. Maka dengan kualitas tersebut, para arifin memiliki perbedaan mendasar dengan manusia lain. Manusia lain seperti gambar tanpa ruh, sedangkan mereka ruh itu sendiri, manusia pada umumnya dzahir, sedang mereka adalah batinya, manusia lain ibarat bangunan fisik (mabani) sedangkan mereka adalah arti (ma'ani), manusia lain sebagai wujud kasar (jahr) sedangkan mereka halus (sirr). Mereka adalah pembela para Nabi, beramal dengan amal para Nabi. Dan inilah makna kalimat bahwa ulama merupakan pewaris para Nabi. ${ }^{72}$

Konsepsi sufistik al-Jailani adalah konsepsi sufistik yang murni, dilandasi oleh ketentuan syari'at Ilahi. Ia melarang seseorang mencebur dalam dunia sufi sebelum orang itu matang dan kuat syariatnya. Sebab, hubungan syari'at di antara thariqah,

\footnotetext{
${ }^{70}$ AbdulQa dir a l-Jailani, Fath ar-Rabbani (Libanon:Dar al-Kutb al-Ilmiah, 2010), h. 52

${ }^{71}$ AbdulQa dir al-Jailani, Fath ar-Rabbani (Libanon: Dar al-Kutb al-Ilmiah, 2010), h. 53.

${ }^{72}$ AbdulQa dir al-Jailani, Fath ar-Rabbani (Libanon: Dar al-Kutb al-Ilmiah, 2010), h. 50
} 
ma'rifah, dan haqiqah adalah sebagaimana yang disabdakan oleh Nabi Muhammad saw. "Syari'at laksana batang pohon, thariqah adalah cabang-cabangnya, ma 'rifah adalah daunnya sedangkan haqiqah adalah buahnya ${ }^{73 "}$ Jadi untuk memetik buahnya seorang sufi harus melalui tahap pengamalan syari'at dengan istiqamah.

\section{KESIMPULAN}

Berdasarkan penelitian dan uraian penjelasan diatas, penulis berkesimpulan bahwa penelusuran konsepsi tasawuf- syariat, al-Jailani mampu memadukan an tara syariat dan sufisme secara praktis-aplikatif. Dan meniscayakan syariat sebagai syarat mutlak untuk meraih keselamatan di dunia dan akhirat, dan kunci penting untuk sampai pada kedekatan dengan-Nya. Al-Jailani juga mengungkapkan bahwa ma' rifat harus dilalui dengan mujahadah dan pembersihan diri.

Karena memang pada dasarnya al-Jailani memakai konsepsi tasawuf yang dilandasi al-Qur'an dan Hadits, dan berorientasi pada alur teologis ahlus sunnah wal jama'ah, juga mengajarkan bahwa orang bertasawuf harus seimbang berhubungan dengan Sang Khalik dan sesama manusia.

Dunia dipandang olehnya sebagai proses kontinuitas kehidupan akhirat yang keduanya tidak bisa dipisahkan. Sufisme dalam pandangan al-Jailani merupakan sufisme yang progresif, aktif dan positif, tidak meninggalkan gelanggang dunia sebagai mazra'ah al-akhirah. Ia memandang dunia dalam keseimbangan akhirat.

\section{DAFTAR PUSTAKA}

Abdul al-Raziq al-Kaylani, al-Syaikh Abdul Qadir Al-Jailani : al-Imam al-Zahid alQudwah, Damaskus: Dar al-Qalam, 1994

Abdul Qadir Al-Jailani, al-Ghunyah li Thalib Thariq al-Haqq, Vol. I, Beirut: Dar alIhya at-Turats al-'Arab, 1996.

Abdul Qadir Al-Jailani, Futuhul Ghoib, Maktabah wa Matba'ah Mushtofa al-Yabi, tt. Abdul Qadir Al-Jailani, al-Fath ar-Rabbany wa al-Faidh ar-Rahmany, Kairo: Dar arRayyan li at-Turats, tt

\footnotetext{
${ }^{73}$ AbdulQa diral-Jailani, Sirral-Asrar wa Madhharal-Anwar (Kairo: Mathba'ahal-Mishriyah tt)h.62
} 
Abdul Qadir Al-Jailani, Futuhul Ghoib Penyingkap Keghaiban (Titah Surga: Yogyakarta, 2015),

Abdul Qadir Al-Jailani, Sirr al-Asrar, wa Madhhar al-Anwar, Kairo: Mathba'ah alMishriyah

Abdul Qadir Al-Jailani, Tafsir Al-Jailani, Dar al-Kotob Al-Ilmiyah:Beirut, 2014

Abdul Qadir bin Habibullah as-Sindi, at-Tashawuffi Mizanil Bahtsi wa Tahqiq, Darul Manar, 1995, cet.II.

Abu Hasan An-Nadwi, Rijal Al-Fikri wa Ad-Dakwah fi Al-Islam, Kuwait Dar AlQalam, 1969)

Ahmad Kamaluddin Hilmi, As-Salajiqah fi-at Tarikh wa al-Hadharah, Kuwait: Dar Al-Buhuts al-Ilmiah, 1975.

Aik Iksan Anshori, Tafsir Ishari Pendekatan Hermeneutika Sufistik Tafsir Abdul Qadir al-Jailani, Ciputat: 2012

Al-Sha'rani, Tabaqat al-Kubra, Kairo: Dar al-Fikr al-Arabi,tt.

Anis Masduki, Metode Tafsir Sufistik Abdul Qadir Al-Jailani, Yogyakarta: STIQ anNur, 2010), cet.1.

Echlos, John M. dan Hassan Shadily, Kamus Inggris-Indonesia (Jakarta: PT. Gramedia Pustaka Utama, 2003)

Fuadi, Moh. Ashif \& Rustam Ibrahim, Implementasi Tasawuf Syekh Abdul Qadir alJailani dalam Majelis Manakib al-Barokah Ponorogo, Jurnal Al-Adabiya: Jurnal Kebudayaan dan Keagamaan, Vo. 15 No. 02 Juli-Desember 2020

Hasyim, Ahmad Umar, Menjadi Muslim Kaffah Berdasarkan Al-Qur`an dan Sunah Nabi saw, diterjemahkan oleh Joko Suryanto dari buku, "Syahshiyah Muslim”, (Makkah: Maktabah al-Tijariyyah), cet. ke-2, (Yogyakarta: Mitra Pustaka, 2005 Ibrahim Madkur, Fi Falsafah Islamiyah Manhaj, wa Tathbiquhu, Kairo: Dar alMa'arif, 1976.

Ismail, Asep Usman dkk., dalam Sri Mulyati, (ed), Tasawuf, cet. ke-1, (Jakarta: Pusat Studi Wanita UIN Syarif Hidayatullah Jakarta, 2005)

Junaidi, Mahbub, Pemikiran Kalam Syekh Abdul Qadir al-Jailani, e-Jurnal Unisda.ac.id

Kafrawi, Pemikiran Syekh Abdul Qadir Al-Jailani Tentang Ma'rifat, Jurnal Al-Liqo Pendidikan Islam, Vol. V, No. 1, 2020 
Martin Van Bruinessen, Kitab Kuning, Pesantren dan Tarekat (Gading Publishing: Yogyakarta, 2015

Mas’ud, Ali \& Ah. Zakki Fuad, Fiqih dan Tasawufdalam Pendekatan Historis, Jumal HUMANIS Vol. 10, No. 1, Januari 2018.

Moleong, Lexy J., Metodologi Penelitian Kualitatif(Bandung: Remaja Rosdakarya. 2013), cet. 31

Muhammad Fadil Al-Jailani, Nahr al-Qadiriyah, Istanbul: Markaz Al-Jailani li alBuhuts al-Ilmiyah, 2009. cet. 1

Nasotion, S, Metode Research Penelitian Ilmiah (Jakarta: Bumi Aksara, 2002), cet.5

Riduan, Belajar Mudah Penelitian Untuk Guru, Karyawan dan Peneliti Pemula (Bandung: Alfabeta, 2015)

Silis, David L. (ed), International Encyclopedia of the Sosial Sciences, Vol.7 (New York: The Macmillan Company \& The Free Press, 1986), 
Integrasi Konsep Tasawuf-Syariat Syaikh Abdul Qadir Al-Jailani (Qutubul Auliya)

Vol. 7. No. 1. April 2021

Halaman 1 - 28 